\title{
A comparison of diabetic polyneuropathy in Type II diabetic BBZDR/Wor rats and in Type I diabetic BB/Wor rats
}

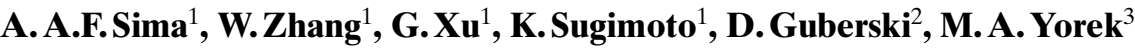 \\ ${ }^{1}$ Departments of Pathology and Neurology, Wayne State University, Detroit, Michigan, USA \\ ${ }^{2}$ Biomedical Research Models Inc., Worcester, Massachusetts, USA \\ ${ }^{3}$ Department of Medicine, University of Iowa, Iowa City, Iowa, USA
}

\section{Abstract}

Aims/hypothesis. To examine the functional, metabolic and structural abnormalities in peripheral nerve in the spontaneously Type II (non-insulin-dependent) diabetic BBZDR/Wor rat and compare these data with those in the Type I (insulin-dependent) diabetic $\mathrm{BB} /$ Wor rat.

Methods. Animals were examined at 6 and 14 months of diabetes. Nerve conduction velocity was measured longitudinally. Nerve polyols were analysed using gas liquid chromatography and $\mathrm{Na} / \mathrm{K}^{+}$-ATPase activity was measured enzymatically. Light and electron microscopic techniques were used for nerve morphometry.

Results. Diabetic BBZDR/Wor rats showed a slowly progressive nerve conduction defect that reached $17 \%(p<0.01)$ at 14 months. There was a decrease in $\mathrm{Na}^{+} / \mathrm{K}^{+}$-ATPase of $35 \%(p<0.05)$. Structurally, there were mild myelinated fibre atrophy $(p<0.05)$, mild or absent changes of the node of Ranvier, but significant $(p<0.001)$ segmental demyelination and Wallerian degeneration. These findings point to a more severe nerve conduction defect, severe myelinated fibre atrophy and profound nodal changes in Type I spontaneously diabetic BB/Wor rats maintained at the same hyperglycaemic concentrations.

Conclusion/interpretation. We conclude that other factors, beside hyperglycaemia, are involved in the pathogenesis of the more severe Type I diabetic neuropathy which possibly involve insulin and C-peptide deficiencies. [Diabetologia (2000) 43: 786-793]

Keywords Neuropathy, Type I and Type II diabetes, electrophysiology, structural changes.
Diabetic polyneuropathy (DPN) is the most common symptomatic chronic complication of diabetes $[1,2]$. It occurs in both Type I (insulin-dependent) and Type II (non-insulin-dependent) diabetic patients and has traditionally been assumed to be the consequence of hyperglycaemia and hence the result of

Received: 24 November 1999 and in revised form: 17 January 2000

Corresponding author: A. A.F. Sima, MD, PhD, Department of Pathology, Wayne State University, 540 E Canfield Ave, Detroit, Mich. 48201, USA

Abbreviations: DPN, Diabetic polyneuropathy; BBZ rat, BBZDR/Wor rat; BB/Wor-rat, Bio-Breeding Worcester rat; MNCV, motor nerve conduction velocity; $\left[\mathrm{Na}^{+}\right]_{\mathrm{i}}$, intracellular sodium. the same underlying pathogenetic factors in the two types of diabetes. We have, however, previously shown structural and electrophysiological differences between the DPN's in the two types of human diabetes $[3,4]$, suggesting that in addition to hyperglycaemia other pathogenetic factors may be involved in this complication.

The BBZDR/Wor (BBZ) rat is a new animal model of human Type II diabetes. It is characterised by spontaneous onset of diabetes at approximately 70 days of age, which is preceded by obesity. It shows insulin resistance with hyperglycaemia and hyperinsulinaemia as well as hyperlipidaemia, hypercholestrolaemia and mild hypertension [5, 6]. Thus, this model mimics closely human Type II diabetes. In contrast, the BB/Wor-rat which also shows spontaneous onset of diabetes at age 70-80 days, develops 
acute onset of hyperglycaemia due to an immune mediated destruction of insulin-producing pancreatic beta cells. It develops severe insulinopaenia and hyperglycaemia and requires daily insulin doses for its survival and therefore mimics human Type I diabetes $[7,8]$. Our laboratory has characterised in detail the metabolic, functional and structural abnormalities occurring in peripheral nerve in this Type I diabetic model [9-14].

The neuropathy in this model is characterised by early nodal and paranodal axonal swelling occurring consequent to intra-axonal $\left[\mathrm{Na}^{+}\right]_{\mathrm{i}}$ accumulation which in turn is related to a defect in $\mathrm{Na}^{+} / \mathrm{K}^{+}$-ATPase activity [11]. This is followed by disruption of the adherence of terminal myelin loops to the paranodal axolemma (axoglial dysjunction) followed by paranodal demyelination and degeneration of the paranodal apparatus [10]. Concomitantly there is progressive distal to proximal axonal atrophy, reflected by a decreased axon/ myelin ratio and excessive myelin wrinkling. Axonal atrophy ultimately leads to Wallerian degeneration [12]. Since nerve fibre regeneration is impaired in the $\mathrm{BB} /$ Wor-rat [13], this together with Wallerian degeneration results in progressive nerve fibre loss.

The aims of our study were to characterise the metabolic, functional and structural abnormalities of DPN in the Type II diabetic BBZ rat and to compare these data with those in the Type I diabetic BB/Wor rat. These comparisons are justified by the fact that both models show spontaneous onset of diabetes at the same age and that they were maintained at similar hyperglycaemic concentrations. Although the comparisons are based on measurements in the two models obtained at different time points, the methodologies used in the various studies were basically the same.

\section{Materials and methods}

Animals. Sixteen prediabetic male BBZ-rats and 12 agematched lean male non-diabetic control rats were obtained from Biomedical Research Models (Worcester, Mass., USA). All animals were maintained in air-filtered cages with ad libitum access to water and rat chow (Wayne Lab Blox F-6, Wayne Feed Division, Chicago, Ill., USA). Body weight and glucosuria (Keto-Diastix, Bayer, Elkhart, Ind., USA) were monitored daily to ascertain the onset of diabetes in diabetes-prone animals. Blood glucose concentrations were measured in tail vein blood samples biweekly and glycated haemoglobin (DCA 2000 Analyzer, Bayer, Elkhart, Ind., USA) was measured bimonthly. Groups of eight diabetic and six control rats were killed at 6 and 14 months of diabetes. The animals were cared for in accordance with guidelines of the Animal Investigation Committee, Wayne State University and those of NIH (publication no. 85-23, 1995).

Electrophysiological studies. Animals were anaesthetised with ethyl ether. Motor nerve conduction velocity (MNCV) was determined in the sciatic-tibial conducting system. Hindlimb skin temperature was monitored by a thermistor and maintained between $36^{\circ} \mathrm{C}$ and $38^{\circ} \mathrm{C}$ by radiant heat and a warming pad. The left sciatic-tibial nerves were stimulated proximally at the sciatic notch and distally at the ankle by bipolar electrodes with supramaximal stimuli $(8 \mathrm{~V})$ at $20 \mathrm{~Hz}$ with a pulse width of $100 \mu$ s delivered by a Cadwell 5200 A electromyographer (Cadwell Laboratories, Kennewick, Wash., USA). The latencies of the compound muscle action potentials were recorded by bipolar electrodes from the first interosseous muscle of the hind paw and measured from the stimulus artifact to the onset of the negative M-wave deflection. We calculated MNCV by subtracting the distal latency from the proximal latency measured in msec and the results were divided into the distance between the stimulating and recording electrode measured in $\mathrm{mm}$, yielding a value for $\mathrm{MNCV}$ in $\mathrm{ms}^{-1}$. Each recording represents the average of 16 measurements. We measured MNCVs weekly from the onset of diabetes to 6 weeks duration and thereafter on a monthly basis. There was no evidence to suggest that repeated anaesthesias in individual animals affected their diabetic conditions.

Tissue collection. On the day of the final MNCV measurements (6 and 14 months duration of diabetes) non-fasted animals were killed between 0800 and 1000 . They were anaesthetised with intraperitoneal sodium pentobarbital $(50 \mathrm{mg} /$ $\mathrm{kg}$ ). Cardiac blood was drawn, centrifuged and snap frozen for examination of serum insulin and C-peptide concentrations. In addition to 6 months diabetic BBZ and control rats, cardiac blood was also obtained from 6 months Type I diabetic $(n=6)$ and control $(n=6) \mathrm{BB} /$ Wor rats. Midthigh segments of both sciatic nerves were removed, weighed and processed for enzymatic ATPase measurements and gas liquid chromatographic determination of polyols as described previously [15]. The right sural nerve (opposite to the side of MNCV measurements) was fixed in situ for $10 \mathrm{~min}$ with cacodylate buffered ( $\mathrm{pH} 7.4$ ) $2.5 \%$ glutaraldehyde, then immersed in the same fixative for $2 \mathrm{~h}$ at $4{ }^{\circ} \mathrm{C}$ and post-fixed in $1 \%$ cacodylate buffered ( $\mathrm{pH} 7.40$ ) osmium tetroxide, dehydrated and embedded in Epon as described previously in detail [14].

Insulin and C-peptide concentrations. Serum insulin and Cpeptide concentrations were examined commercially, using RIA kits by Linco Research (St. Charles, Mo., USA).

Biochemical analyses. For the measurements of nerve glucose, sorbitol, fructose and myoinositol, sciatic nerve samples were homogenised in $2 \mathrm{ml}$ of $5 \%$ trichloroacetic acid. Aldonitrile derivatives were formed by addition of $0.3 \mathrm{ml}$ hydroxylamine in pyridine-methanol 4:1 (vol:vol). The samples were sonicated for $1 \mathrm{~min}$ and $1 \mathrm{ml}$ of acetic anhydride was added and samples were washed in $1.0 \mathrm{~N} \mathrm{HCl}$. Samples were reconstituted in 2butanane and analysed gas liquid chromatographically as described previously [15].

$\mathrm{Na}^{+} / \mathrm{K}^{+}$-ATPase was measured as described previously [15]. Nerve samples were homogenised in $2 \mathrm{ml}$ of $0.2 \mathrm{~mol} / 1$ sucrose plus $0.02 \mathrm{~mol} / \mathrm{l} \mathrm{TRIS}-\mathrm{HCl}$ at $\mathrm{pH} 7.5$. Ten to $20 \mu \mathrm{l}$ of the homogenate was assayed enzymatically for total ATPase in $1 \mathrm{ml}$ of $100 \mathrm{mmol} / \mathrm{l} \mathrm{NaCl}, 10 \mathrm{mmol} / \mathrm{l} \mathrm{KCl}, 2.5 \mathrm{mmol} / \mathrm{l} \mathrm{MgCl}_{2}, 1 \mathrm{mmol} / \mathrm{l}$ TRIS ATP, $1 \mathrm{mmol} / 1$ phosphoenolpyruvate, $30 \mathrm{mmol} / 1$ imidazole $\mathrm{HCl}$ buffer (pH 7.30), $0.15 \mathrm{mmol} / \mathrm{l} \mathrm{NADH}, 50 \mu \mathrm{g}$ lactate dehydrogenase and $30 \mu \mathrm{g}$ pyruvate kinase. To measure ouabain-inhibitable ATPase, $20 \mu \mathrm{l}$ of $25 \mathrm{mmol} / \mathrm{l}$ ouabain was added. Ouabain-inhibitable $\mathrm{Na}^{+} / \mathrm{K}^{+}$-ATPase activity was defined as the difference in activity before and after the addition of ouabain and was expressed as micromoles ADP formed per gram of wet weight per hour. 
Morphometric analyses. Semithin $(0.5 \mu \mathrm{m})$ cross-sections of Epon-embedded sural nerves were stained with paraphenylene diamine for light microscopic morphometric analysis using a computerised image analysis system (Image-1, Universal Imaging, West Chester, Pa., USA). This system is programmed for assessment of the total complement of sural nerve myelinated fibres and provides the following measures: mean myelinated fibre size $\left(\mu \mathrm{m}^{2}\right)$, myelinated fibre density (number $/ \mathrm{mm}^{2}$ ), coefficient of variation $(\mathrm{CV})$ of myelinated fibre densities between image frames (a measure of focal nerve fibre loss), myelinated fibre occupancy (\% of endoneurial area) and axon/myelin ratio as previously described [14].

Teased fibre examination. A mean of $172 \pm 5$ myelinated fibres were teased in unpolymerised Epon from each sural nerve and scored for specific pathologic changes, providing a three dimensional assessment of myelinated fibres, as described previously in detail [14]. The pathologic changes in DPN evolve from mild to increasingly severe structural changes involving the nodal apparatus, the axon, and the myelin sheath [14]. Representing the temporal sequence and increasing severity of specific structural changes, they can be classified as follows: normality, paranodal swelling, paranodal demyelination, excessive myelin wrinkling, intercalated internodes, segmental demyelination, Wallerian degeneration, and remyelination/regeneration. Each fibre was scored as to its most severe change and the number of fibres in each category was expressed as a percentage of total fibres examined.

Axoglial dysjunction. Disruption of the paranodal ion-channel barrier (axoglial dysjunction) is a characteristic abnormality of DNP in Type I diabetic rodent models and humans [3, 10]. The frequency of axoglial dysjunction was examined electronmicroscopically from a mean of $17.9 \pm 1.1$ paranodal areas in each sural nerve. Serial longitudinal sections were systematically examined for the absence of axoglial junctions between terminal myelin loops and the axolemmal membrane as described in detail earlier [16]. The frequency of myelin loops totally devoid of axoglial junctions was expressed as a percentage of the total myelin loops examined.

Statistical analysis. The results are presented as mean \pm SD and the significance of differences was calculated by analysis of variance (ANOVA). When an overall difference of $p<0.05$ was obtained, group differences were assessed by post hoc analysis using the Student-Newman-Keuls test.

\section{Results}

Body weight and hyperglycaemia. Diabetic BBZ rats showed increased body weights at both 6 and 14 months of diabetes compared with age-matched control rats $[522 \pm 41$ vs $414 \pm 11 \mathrm{~g}(p<0.05)$ at 6 months and $593 \pm 43$ vs $506 \pm 13 \mathrm{~g}$ (NS) at 14 months]. Blood glucose and glycated haemoglobin were both significantly $(p<0.001)$ increased in diabetic animals at both time points (blood glucose: 6 months, $20.5 \pm 0.8$ vs $5.9 \pm 0.2 \mathrm{mmol} / \mathrm{l} ; 14$ months, $22.1 \pm 0.9$ vs $5.8 \pm 0.3 \mathrm{mmol} / \mathrm{l}$; glycated haemoglobin: 6 months, $13.0 \pm 0.2$ vs $5.3 \pm 0.2 \% ; 14$ months, $14.8 \pm 0.2$ vs $5.3 \pm 0.1 \%$ in diabetic and control rats respectively).

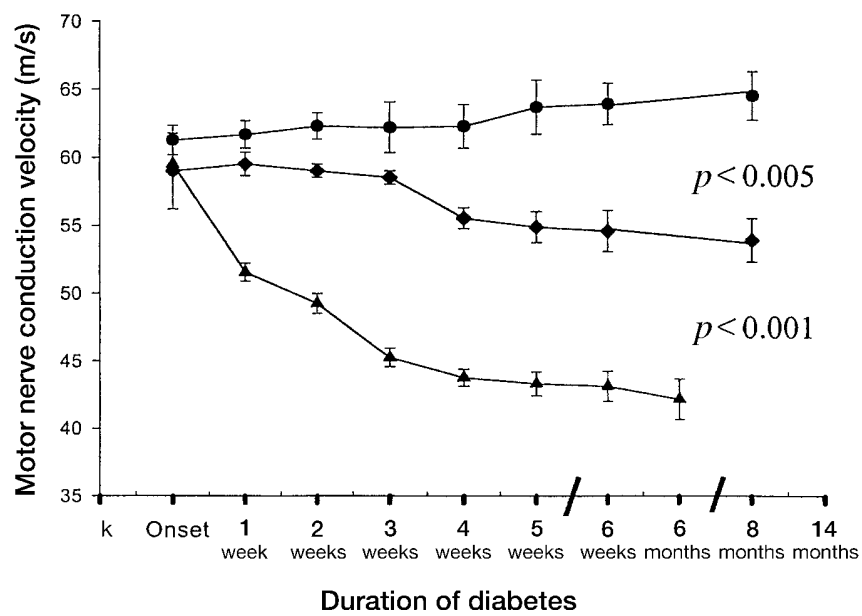

Fig. 1. Nerve conduction slowing in Type II BBZ rats is compared with that in Type I BB/Wor rats and non-diabetic ageand sex-matched control rats. Note a more rapid decrease and severely acute (metabolic) nerve conduction defect in diabetic $\mathrm{BB} /$ Wor rats, which also show a significantly $(p<0.001)$ more severe chronic (structurally related) nerve conduction defect compared with Type II BBZ rats. Control $(n=12) ; \boldsymbol{\Lambda}$, $\mathrm{BB} /$ Wor $(n=8) ; \diamond$ BBZ $(n=16)$

Motor nerve conduction velocity. Following onset of diabetes, BBZ rats showed a slowly progressive decrease in MNCV during the first 6 weeks of diabetes (Fig. 1). At 6 months of diabetes the MNCV was reduced by $11 \%$ or $6.7 \mathrm{~m} / \mathrm{s}(p<0.05)$ compared with age-matched non-diabetic control rats. This conduction defect increased to $17 \%$ or $11.4 \mathrm{~m} / \mathrm{s}(p<0.005)$ at 14 months of diabetes (Fig. 1).

Serum insulin and C-peptide concentrations. At 6 months of diabetes, non-fasting serum insulin and C-peptide concentrations were measured between 0800 and 1000 in BBZ rats $(n=8)$ and $\mathrm{BB} /$ Wor rats $(n=6)$ and their respective age- and sex-matched controls $(n=6)$ in both control groups). In control rats no significant differences were found in insulin concentrations (BBZ controls $516.6 \pm 51.7$ vs BB/ Wor controls $430.5 \pm 155 \mathrm{pmol} / \mathrm{l})$. In diabetic rats, however, BB/Wor rats $(n=6)$ showed significantly $(p<0.001)$ lower insulin concentrations compared with diabetic BBZ rats $(n=8) \quad(51.7 \pm 0.0$ vs $585.5 \pm 68.9 \mathrm{pmol} / \mathrm{l}$, respectively). Diabetic BBZ showed a non-significant $13 \%$ increase in insulin concentrations compared with controls.

No differences were found in C-peptide concentrations between $\mathrm{BBZ}$ control, BB/Wor control and BBZ diabetic rats $(705 \pm 195$ vs $711 \pm 121$ vs $752 \pm 26$ $\mathrm{nmol} / \mathrm{l}$, respectively). Diabetic BB/Wor rats, however, showed significantly $(p<0.001)$ decreased C-peptide concentrations $(39 \pm 11 \mathrm{nmol} / \mathrm{l})$ compared with the other groups.

Sciatic nerve glucose, fructose, sorbitol, and myoinositol contents. Nerve glucose concentrations were sig- 
Table 1. Effect of Type I diabetes on sural nerve fascicular and myelinated fibre morphometry

\begin{tabular}{|c|c|c|c|c|c|c|}
\hline Animals & $\begin{array}{l}\text { Myelinated } \\
\text { fibre density } \\
\left(\text { number } / \mathrm{mm}^{2}\right)\end{array}$ & $\begin{array}{l}\text { Myelinated } \\
\text { fibre size } \\
\left(\mu \mathrm{m}^{2}\right)\end{array}$ & $\begin{array}{l}\text { Axon/myelin } \\
\text { ratio }\end{array}$ & $\begin{array}{l}\text { Mean myelinated } \\
\text { fibre occupancy } \\
(\%)\end{array}$ & $\begin{array}{l}\text { Focality of } \\
\text { fibre loss }(\mathrm{CV}) \\
\%\end{array}$ & $\begin{array}{l}\text { Total fascicular } \\
\text { area } \\
\left(\mu \mathrm{m}^{2}\right)\end{array}$ \\
\hline \multicolumn{7}{|l|}{6 months } \\
\hline Diabetic rats $(n=5)$ & $16184 \pm 677$ & $29.7 \pm 1.3^{1}$ & $0.58 \pm 0.01$ & $60.3 \pm 2.2$ & $19.6 \pm 2.3$ & $32108 \pm 2526$ \\
\hline \multicolumn{7}{|l|}{14 months } \\
\hline Control rats $(n=4)$ & $12418 \pm 201$ & $45.1 \pm 0.8$ & $0.59 \pm 0.01$ & $56.0 \pm 1.0$ & $16.2 \pm 2.2$ & $33302 \pm 2053$ \\
\hline
\end{tabular}

${ }^{1} p<0.05$ vs control

${ }^{2} p<0.005$ vs control

nificantly increased in diabetic sciatic nerves both at 6 and 14 months $[22.70 \pm 2.85$ vs $5.13 \pm 0.56 \mu \mathrm{mol} / \mathrm{g}$ $(p<0.001)$ and $6.37 \pm 1.85$ vs $1.01 \pm 0.23(p<0.01)$, respectively]. Glucose concentrations, however, were significantly $(p<0.01)$ decreased in both control and diabetic rats at 14 months compared with the concentrations in respective groups at 6 months. Sciatic nerve sorbitol concentrations were significantly increased in BBZ rats at both 6 and 14 months $[1.26 \pm 0.03$ vs $0.37 \pm 0.04 \mu \mathrm{mol} / \mathrm{g} \quad(p<0.001)$ and $1.44 \pm 0.34$ vs $0.37 \pm 0.07 \mu \mathrm{mol} / \mathrm{g}(p<0.05)$, respectively]. Control rats showed no detectable fructose concentrations at either 6 or 14 months. Diabetic rats, however, showed significantly increased fructose concentrations at 6 months $(1.42 \pm 0.15 \mu \mathrm{mol} / \mathrm{g}$; $p<0.01)$, as well as at $14 \mathrm{months}(0.90 \pm 0.33 \mu \mathrm{mol} / \mathrm{g}$; $p<0.05)$. Despite significantly lower sciatic nerve glucose concentrations at 14 months as compared with 6 months, sorbitol concentrations were comparable at the two time points suggesting an increased aldose reductase activity in the more chronically diabetic BBZ rats. Fructose concentrations were insignificantly lower in sciatic nerves of 14 months diabetic rats compared with 6 months. Sciatic nerve myoinositol concentrations were not significantly altered in 6 months diabetic BBZ rats (diabetic $4.24 \pm 0.26$ vs control $4.92 \pm 0.38 \mu \mathrm{mol} / \mathrm{g}$ ) but were significantly increased in 14 months diabetic rats compared with age-matched control rats $(8.93 \pm 1.08$ vs $6.28 \pm$ $0.43 \mu \mathrm{mol} / \mathrm{g} ;(p<0.05)$ respectively $)$.

$\mathrm{Na}^{+} / \mathrm{K}^{+}$-ATPase activity. Total $\mathrm{Na}^{+} / \mathrm{K}^{+}$-ATPase activity was not significantly altered in 6 months diabetic $\mathrm{BBZ}$ rats, whereas in 14 months diabetic rats it was significantly reduced by $25 \% \quad(p<0.03$; data not shown). The ouabain inhibitable fraction was reduced significantly by 36 and $27 \%$ in 6 and 14 months diabetic rats respectively [6 months: $61.9 \pm 6.2$ vs $96.4 \pm 11.6 \mu \mathrm{mol}$ ADP $\cdot \mathrm{g}^{-1} \cdot \mathrm{h}^{-1}(p<0.05) ; 14$ months: $67.1 \pm 6.3$ vs $91.6 \pm 6.1 \mu \mathrm{mol} \quad \mathrm{ADP} \cdot \mathrm{g}^{-1} \cdot \mathrm{h}^{-1} \quad(p<$ $0.05)]$.
Morphometric abnormalities. At 6 months of diabetes, BBZ rats showed significant atrophy of myelinated fibres $(p<0.05)$, which on average were $22 \%$ smaller than those of age-matched control rats (Table 1). There were no significant changes in myelinated fibre density, axon/myelin ratio, myelinated fibre occupancy or in total sural nerve fascicular area (Table 1). There was an insignificant $22 \%$ increase in the focality of fibre loss in diabetic BBZ rats.

At 14 months of diabetes there was a mild but significant $11 \%$ loss $(p<0.05)$ of myelinated fibres as indicated by myelinated fibre density (Table 1). This was associated with a significant myelinated fibre atrophy $(p<0.05)$ and reduced fibre occupancy $(p<0.005)$ (Table 1$)$. As in 6 months diabetic rats there was an insignificant $20 \%$ increase in the focality of fibre loss. No change was found in the ratio between axonal and myelin sizes (Table 1), suggesting that the axon and myelin sheath were on average affected to the same extent.

Teased fibre changes. The frequency of structurally normal fibres was significantly $(p<0.001)$ decreased in 6 months diabetic rats (Table 2). This was accounted for by a fivefold $(p<0.001)$ increase in the frequency of fibres showing excessive myelin wrinkling and by a fourfold $(p<0.005)$ increase in fibres showing segmental demyelination (Table 2). Increased frequencies of paranodal swelling, paranodal demyelination or intercalated internodes were not shown in sural nerves of 6 months diabetic rats (Table 2).

In 14 months diabetic BBZ rats only $69.2 \pm 1.8 \%$ $(p<0.001)$ of sural nerve myelinated fibres showed normal morphology (Table 2). Although there was no significant increase in paranodal swelling, paranodal demyelination was significantly $(p<0.005)$ increased. The major pathology consisted of axonal atrophy as assessed by excessively wrinkled myelinated fibres, which was increased sixfold $(p<0.001)$. Segmental demyelination was increased fourfold $(p<0.001)$ and Wallerian degeneration almost 40 fold $(p<0.001)$. The frequency of regenerating fibres was significantly $(p<0.01)$ increased in 14 months diabetic BBZ-rats (Table 2). 
Table 2. Teased fibre abnormalities in 6 and 14 months diabetic BB/Z rats

\begin{tabular}{|c|c|c|c|c|c|c|c|c|}
\hline Animals & $\begin{array}{l}\text { Normality } \\
(\%)\end{array}$ & $\begin{array}{l}\text { Paranodal } \\
\text { swelling } \\
(\%)\end{array}$ & $\begin{array}{l}\text { Paranodal } \\
\text { demyelina- } \\
\text { tion } \\
(\%)\end{array}$ & $\begin{array}{l}\text { Intercalated } \\
\text { internodes } \\
(\%)\end{array}$ & $\begin{array}{l}\text { Excessive } \\
\text { myelinated } \\
\text { wrinkling } \\
(\%)\end{array}$ & $\begin{array}{l}\text { Segmental } \\
\text { demyelina- } \\
\text { tion } \\
(\%)\end{array}$ & $\begin{array}{l}\text { Wallerian } \\
\text { degeneration } \\
(\%)\end{array}$ & $\begin{array}{l}\text { Regenera- } \\
\text { tion } \\
(\%)\end{array}$ \\
\hline \multicolumn{9}{|l|}{6 months } \\
\hline Control rats $(n=5)$ & $96.6 \pm 0.3$ & $1.5 \pm 0.2$ & $0.3 \pm 0.2$ & $0.2 \pm 0.2$ & $0.9 \pm 0.3$ & $0.6 \pm 0.3$ & 0 & 0 \\
\hline Diabetic rats $(n=5)$ & $88.7 \pm 1.0^{1}$ & $1.8 \pm 0.4$ & $1.1 \pm 0.4$ & $0.2 \pm 0.2$ & $4.9 \pm 0.5^{1}$ & $2.5 \pm 0.4^{2}$ & $0.7 \pm 0.4$ & $0.2 \pm 0.2$ \\
\hline \multicolumn{9}{|l|}{14 months } \\
\hline
\end{tabular}

Axoglial dysjunction. Since disruption of the paranodal barrier is a late occurring progressive change, this abnormality was assessed only in 14 months diabetic BBZ rats. A mean of 18 paranodes was examined ultrastructurally in each sural nerve. No difference was found in the frequency of dislodged myelin loops (axoglial dysjunction) between diabetic (11.8 \pm $1.8 \%)$ and age-matched control rats $(12.3 \pm 1.2 \%)$.

\section{Discussion}

The spontaneously diabetic BBZ rat is a recently characterised model of insulin-resistant human Type II diabetes [5, 6]. In our study, we have shown a slowly progressive and relatively mild neuropathy in this model, despite the fact that the animals stayed severely hyperglycaemic for 14 months. The nerve conduction defect evolved slowly and reached $11 \%$ at 6 months of diabetes compared with non-diabetic control rats, and $17 \%$ at 14 months. These changes were accompanied by activation of the polyol pathway as reflected by a 3.5-fold increase in sciatic nerve sorbitol but by an insignificant depletion of nerve myoinositol at 6 months of diabetes. The latter was increased, however, by $40 \%$ in chronically diabetic BBZ rats, suggesting alternative osmoregulatory mechanisms following the polyol pathway activation at this stage of diabetes [17]. Despite significantly lower sciatic nerve glucose concentrations at 14 months compared with 6 months, sorbitol concentrations were comparable at the two time points. These differences suggest an increased aldose reductase activity in the more chronically diabetic BBZ rats which contrast with those observed in the Type I $\mathrm{BB} /$ Wor rats, in which there appears to be a decreased aldose reductase activity with progression of the neuropathy [14]. Therefore the dynamics of the polyol pathway may differ in the two models. The nerve conduction defect was associated with a $36 \%$ deficit in nerve $\mathrm{Na}^{+} / \mathrm{K}^{+}$-ATPase. The neuronal $\mathrm{Na}^{+} /$ $\mathrm{K}^{+}$-ATPase defect has been associated with impaired inactivation of nodal Sodium channels resulting in decreased nodal membrane $\left[\mathrm{Na}^{+}\right]$potentials, increased axonal $\left[\mathrm{Na}^{+}\right]_{\mathrm{i}}$ and nodal and paranodal swelling [18], changes which correlate with the acute metabolic nerve conduction defect [11].

Although only mild nerve fibre loss was shown, even after 14 months of diabetes in the BBZ rat, the neuropathy was structurally characterised by diminished myelinated fibre size, axonal atrophy, segmental demyelination and Wallerian degeneration. The myelinated fibre atrophy appeared to affect both axons and myelin to a similar extent, since the axon-myelin ratio was not affected by diabetes. This is supported by the teased fibre evaluations showing a substantial percentage of fibres with axonal atrophy (excessive myelin wrinkling) as well as fibres showing disproportionally thin myelin sheaths associated with segmental demyelination and myelinated fibre regeneration. Hence, these changes influence the axon/myelin in opposite directions and could therefore account for the lack of a change in axon/myelin ratio. Nodal and paranodal structural changes, such as paranodal swelling, paranodal demyelination, axoglial dysjunction and intercalated internodes were absent or mild. This is consistent with earlier findings in sural nerve biopsies from neuropathic Type II diabetic patients, who also lack these changes in contrast to Type I diabetic patients [3]. These findings are not dissimilar from those shown in other Type II diabetic rodent models [19-20].

Compared with the findings in the spontaneously diabetic Type I BB/Wor rat maintained at similar hyperglycaemic concentrations, striking differences are apparent between the neuropathies in the two models. Despite a more severe $\mathrm{Na}^{+} / \mathrm{K}^{+}$-ATPase defect in the BBZ rat [14] and similar increases in nerve sorbitol concentrations [14], the BBZ rat showed a significantly milder NCV defect than the BB/Wor rat (Fig.1). These findings seem to suggest that hyperglycaemia and subsequent polyol pathway activation decreased neural $\mathrm{Na}^{+} / \mathrm{K}^{+}$-ATPase and presumably the consequences of non-enzymatic glycation are only re- 


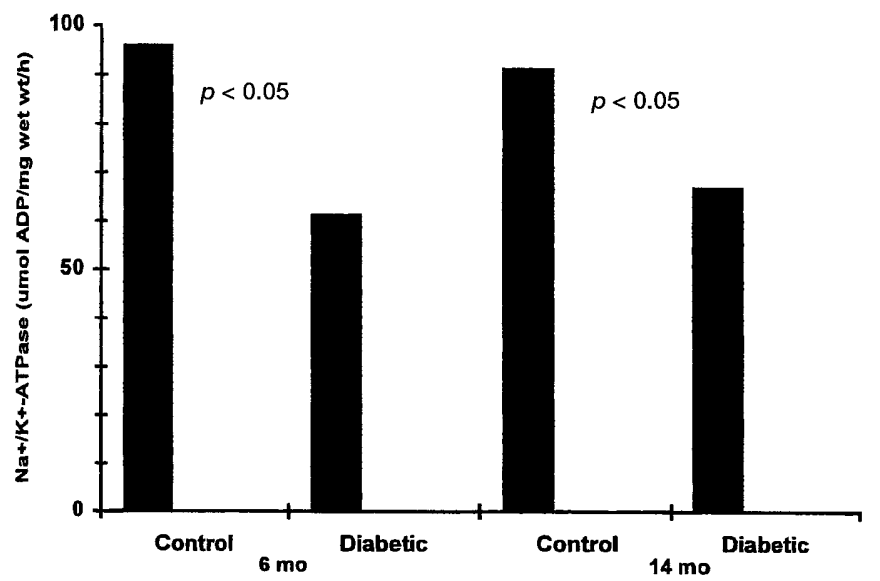

Fig. 2. $\mathrm{Na}^{+} / \mathrm{K}^{+}$-ATPase activity in sciatic nerve from 6 and 14 months diabetic BBZ rats and age-matched control rats

sponsible for a component of the more severe MNCV defect in the $\mathrm{BB} /$ Wor rat. Therefore, besides hyperglycaemia, factors that discriminate between the two models such as insulin and C-peptide deficiencies as shown in the Type I model must be considered as additional pathogenetic elements in Type I DPN. This notion is consistent with the findings in the DCCT study in which strict hyperglycaemic control only partially prevented diabetic neuropathy [22].

The discrepancy between the severity in nerve $\mathrm{Na}^{+} / \mathrm{K}^{+}$-ATPase activity and the relatively mild $\mathrm{MNCV}$ deficit in the BBZ rat compared with the $\mathrm{BB} /$ Wor rat [14] could reflect a more prominent deficit in vascular than neuronal $\mathrm{Na}^{+} / \mathrm{K}^{+}$-ATPase activity in the former model. This assumption is supported by the lack of early paranodal swelling in the BBZ rat, which in the Type I model has been associated with the neuronal $\mathrm{Na}^{+} / \mathrm{K}^{+}$-ATPase defect $[11,18]$. Although not examined in this study, this notion would suggest a more pronounced vascular component with changes in $\mathrm{NO}$ and vasoactive prostaglandins in the BBZ rat, resulting in a more severely compromised nutritive blood flow and endoneurial hypoxia $[23,24]$. The high frequencies of myelinated fibres showing segmental demyelination, Wallerian degeneration and a trend toward increased focality of nerve fibre loss, not seen in the BB/Wor rat [14], are in keeping with a more prominent hypoxic component in the BBZ model. This supposition, however, needs to be examined in detail.

Despite a relatively high frequency of Wallerian degeneration in 14 months diabetic BBZ rats, they only showed mild fibre loss compared with chronically diabetic BB/Wor rats [9], suggesting that nerve fibre regeneration in the Type II model may be less impaired than that in the $\mathrm{BB} /$ Wor rat [13].

The most striking difference between the two models pertains to the nodal and paranodal abnormalities, which are likely to underlie the differences in the severity of the chronic, structurally related,
MNCV deficits [25, 26]. The progressive disruption of the paranodal ion-channel barrier by axoglial dysjunction and subsequent paranodal demyelination characteristic of human and rodent Type I DPN [3, $10,26]$ could not be identified in the BBZ rat even after 14 months of diabetes. These findings are consistent with those in human Type II diabetic neuropathy [3]. Disruption of the paranodal apparatus in the BB/ Wor rat results in lateral migration of $\mathrm{Na}^{+}$channels, and of Schwann cell and axonal GLUT1 and 3 respectively, and in increased $\mathrm{K}^{+}$leakage currents [27-29]. The resulting diminished density of nodal $\mathrm{Na}^{+}$channels is associated with a decrease in nodal $\mathrm{Na}^{+}$permeability and membrane potential and contributes in a major way to the progressive chronic NCV defect in the $\mathrm{BB} /$ Wor rat $[27,29]$.

Since these abnormalities do not occur in the Type II BBZ rat maintained at similar hyperglycaemic concentrations they are not likely to be directly related to hyperglycaemia. They possibly result from insulin and C-peptide deficiencies occurring in Type I but not in Type II diabetes. We have recently shown that the expression of the predominantly high affinity insulin receptor, localised at the paranodal apparatus, is increased in the Type I insulin deficient BB/Wor rat [30]. This abnormality is prevented by replacement of $C$ peptide which, when given over a period of 8 months to diabetic $\mathrm{BB} /$ Wor rats, corrects the MNCV deficit to levels comparable to those seen in Type II BBZ rats and prevents the paranodal structural abnormalities [31]. C peptide has insulin-like effects, although it has no effect on hyperglycaemia [32, 33]. It potentiates insulin's effect with respect to arteriolar blood flow [34], tyrosine phosphorylation of the $\beta$-subunit of the insulin receptor and PI3-kinase activity [35, unpublished data]. The molecular basis for the protective effect of insulin or $\mathrm{C}$ peptide or both on the nodal apparatus in peripheral nerve is not known, but neuroprotective effects of both insulin and $\mathrm{C}$ peptide have been documented. Insulin promotes neurite outgrowth from sensory neurons and neuroblastoma cells [36, 37] and is important for nerve growth factor to exert its effect on human neuroblastoma cells [38]. These effects are mediated by upregulation and stabilisation of tubulin and neurofilament mRNA [37]. The peripheral nerve insulin receptor co-localises with $\mathrm{Na}^{+} / \mathrm{K}^{+}$-ATPase, glucose transporters, $\mathrm{Na}^{+}$channels, aldose reductase, paranodins and ankyrin $_{\mathrm{G}}$ [39-45], molecules all of which play important parts in the integrity of nodal/paranodal function and structure. Thus, it is possible that perturbed insulin signalling due to insulin or C-peptide deficiency or both may in part be responsible for the nodal/paranodal dysfunction and structural abnormalities which appear to set Type I diabetic neuropathy apart from that of Type II diabetes.

In summary, our study has shown a slowly progressive diabetic neuropathy in the normo-insulinaemic 
obese BBZ rat, characterised by a slowly progressive MNCV defect, severely decreased $\mathrm{Na}^{+} / \mathrm{K}^{+}$-ATPase activity, moderate myelinated fibre atrophy, and relatively severe segmental demyelination and Wallerian degeneration. This diabetic model showed only mild nerve fibre loss and failed to show nodal and paranodal changes, characterising the neuropathy in the diabetic Type I BB/Wor rats. We suggest that the differences between the neuropathies in the two types of diabetes are due to the presence or absence of neuroprotective insulin and $\mathrm{C}$ peptide.

Acknowledgements. This study was supported by grants from JDFI and the Thomas Foundation.

\section{References}

1. Pickup JC, William S (1994) Chronic complications of diabetes. Blackwell Science, London

2. Greene DA, Sima AA, Feldman EL, Stevens MJ (1997) Diabetic neuropathy. In: Rifkin H, Porte D, Sherwin R (eds) Ellenberg and Rifkin Diabetes Mellitus, 5th edn. Appleton \& Lange, Stanford, pp 1009-1076

3. Sima AA, Nathaniel V, Bril V, McEwen TA, Greene DA (1988) Histopathological heterogeneity of neuropathy in insulin-dependent and non-insulin-dependent diabetes and demonstration of axo-glial dysjunction in human diabetic neuropathy. J Clin Invest 81: 349-364

4. Bril V, Werb MR, Greene DA, Sima AA (1996) Single fiber electromyography in diabetic peripheral polyneuropathy. Muscle Nerve 19: 2-9

5. Ellis EA, Grant MB, Murray FT et al. (1998) Increased NADH oxidase activity in the retina of the BBZ/WOR diabetic rat. Free Radic Biol Med 24: 111-120

6. Sima AA, Merry AC, Hall DE et al. (1997) The BB/Z $Z^{\mathrm{DR}}$ rat: A model for type II diabetic neuropathy. Exp Clin Endocrinol Diabetes 105: 63-64

7. Mordes JP, Greiner DL, Rossini AA (1996) Animal models of autoimmune diabetes mellitus. In: LeRoith D, Taylor SI, Olefsky JM (eds) Diabetes Mellitus. A fundamental and clinical text. Lippincott-Raven, Philadelphia, pp 349-360

8. Marliss EB, Nakhooda AF, Poussier P, Sima AA (1982) The diabetic syndrome of the BB-Wistar rat. Possible relevance to Type I (insulin dependent) diabetes in man. Diabetologia 22: 225-232

9. Sima AA, Bouchier M, Christensen H (1983) Axonal atrophy in sensory nerves of the diabetic BB-Wistar rat, a possible early correlate of human diabetic neuropathy. Ann Neurol 13: 264-272

10. Sima AA, Lattimer SA, Yagihashi S, Greene DA (1986) "Axo-glial dysjunction": a novel structural lesion that accounts for poorly reversible slowing of nerve conduction in the spontaneously diabetic BB-rat. J Clin Invest 77: 474-484

11. Sima AA, Brismar T (1985) Reversible diabetic nerve dysfunction. Structural correlates to electrophysiological abnormalities. Ann Neurol 18: 21-29

12. Sima AA (1993) The natural history of diabetic neuropathy in the BB-rat. In: Sharma AK (ed) Diabetes mellitus and its complications-an update. Macmillan India Limited, Delhi, pp 315-325

13. Kamijo M, Merry AC, Cherian PV et al. (1996) Nerve fiber regeneration following axotomy in the diabetic BB/W-rat.
The effect of ARI-treatment. J Diabetes Complications 10: 183-191

14. Sima AA, Ristic H, Merry A et al. (1996) Primary preventive and secondary interventionary effects of acetyl-L-carnitine on diabetic neuropathy in the bio-breeding Worcester rat. J Clin Invest 97: 1900-1907

15. Yorek MA, Wiese TJ, Davidson EP et al. (1993) Reduced motor nerve conduction velocity and $\mathrm{Na}^{+} / \mathrm{K}^{+}$-ATPase in rats maintained on a diet containing L-fucose. Reversal by myo-inositol supplementation. Diabetes 42 : 1401-1406

16. Yamamoto K, Merry AC, Sima AA (1996) An orderly development of paranodal axoglial junctions and bracelets of Nageotte in the rat sural nerve. Dev Brain Res 96: $36-45$

17. Stevens MJ, Lattimer SA, Kamijo M et al. (1993) Osmotically induced nerve taurine depletion and the compatible osmolyte hypothesis in experimental diabetic neuropathy in the rat. Diabetologia 36: 608-614

18. Greene DA, Chakrabarti S, Lattimer SA, Sima AA (1987) Role of sorbitol accumulation and myoinositol depletion in paranodal swelling of large myelinated nerve fibers in the insulin-deficient spontaneously diabetic biobreeding rat. J Clin Invest 79: 1479-1485

19. Yagihashi S, Sugimoto K, Wada R (1994) Different neuropathic patterns between type I and type II diabetic animal models. In: Sokamoto N, Alberti KG, Hotta N (eds) Pathogenesis and treatment of NIDDM and its related problems. Elsevier Science, Amsterdam, pp 401-405

20. Yagihashi S, Wada R, Kamijo M, Nagai K (1993) Peripheral neuropathy in the WBN/Kob rat with chronic pancreatitis and spontaneous diabetes. Lab Invest 68: 296-307

21. Sima AA, Sugimoto K (1999) Experimental diabetic neuropathy - an update. Diabetologia 42 773-788

22. The Diabetes Control and Complications Trial Research Group (1993) The effect of intensive treatment of diabetes on development and progression of long-term complications in insulin-dependent diabetes mellitus. New Engl J Med 329 977-986

23. Cameron NE, Cotter MA (1994) The relationship of vascular changes to metabolic factors in diabetes mellitus and their role in the development of peripheral nerve complications. Diab Met Rev 10: 189-224

24. Cameron NE, Cotter MA (1999) Oxidative stress and abnormal lipid metabolism in diabetic complications. In: Sima AA, Shafrir E (eds) Frontiers in Animal Diabetes Research. Chronic Complication in Diabetes, vol 1. Harwood, Amsterdam, pp 97-130

25. Sima AA, Prashar A, Zhang W-X et al. (1990) Preventive effect of long term aldose reductase inhibition (Ponalrestat) on nerve conduction and sural nerve structure in the spontaneously diabetic bio-breeding-rat. J Clin Invest 85 : 1410-1420

26. Sima AA, Greene DA (1996) Nerve morphometry - a valuable tool in the assessment of natural history and electrophysiological correlates in diabetic neuropathy. In: Sharma AK (ed) Morphometry, Applications to Medical Sciences. MacMillan, Delhi, pp 122-133

27. Cherian PV, Kamijo M, Angelides KJ, Sima AA (1996) Nodal $\mathrm{Na}^{+}$-channel displacement is associated with nerve conduction slowing in the chronically diabetic BB/W-rat. Prevention by an aldose reductase inhibitor. J Diabetes Complications 10: 192-200

28. Cherian PV, Brosius FC III, Greene DA, Sima AA (1996) Expression and localization of GLUT1 and GLUT3 in peripheral nerve of diabetic BB/W-rat. Diabetologia 39[Suppl 1]:A172 (Abstract) 
29. Brismar T, Sima AA (1981) Changes in nodal function in nerve fibres of the spontaneously diabetic BB-Wistar rat. Acta Physiol Scand 113: 499-506

30. Sugimoto K, Zhang W, Xu G, Sima AA (1999) Localization of insulin receptor isoforms in rat peripheral nerve. Diabetes 48:[Suppl 1]A151 (Abstract)

31. Sima AA, Zhang W, Xu G (1999) Long-term effect of Cpeptide treatment on type 1 diabetic neuropathy. Diabetes 48:[Suppl 1]A149 (Abstract)

32. Rigler R, Pramanik A, Jonasson P et al. (1999) Specific binding of proinsulin C-peptide to human cell membranes. Proc Natl Acad Sci USA 96: 13378-13383

33. Hoogwert B, Bantle J, Gaenlen H et al. (1986) Infusion of synthetic human C-peptide does not affect plasma glucose, serum insulin, or plasma glucagon in healthy subjects. Metabolism 35: 122-125

34. Jensen ME, Messina EJ (1999) C-peptide induces a concentration-dependent dilatation of skeletal muscles arterioles only in presence of insulin. Am $\mathbf{J}$ Physiol 276:H1223-H1228

35. Sima AA, Srinivas PR, Kammaraju S et al. (1998). Enhancement of insulin receptor activity by C-peptide. Diabetologia 41:A177 (Abstract)

36. Ischii DN (1995) Implications of insulin-like growth factors in the pathogenesis of diabetic neuropathy. Brain Res Rev 20: 47-67

37. Fernyhough P, Willars GB, Lindsay RM, Tomlinson DR (1993) Insulin and insulin-like growth factor I enhances regeneration in cultured adult rat sensory neurons. Brain Res 607: $117-124$

38. Recio-Pinto E, Lang FF, Ischii DN (1984) Insulin and insulin growth factor II permit nerve growth factor binding and the neurite formation response in cultured human neuroblastoma cells. Proc Natl Acad Sci USA 81: 2562-2566

39. Powell HC, Garrett RS, Kador PF, Mizisin AP (1991) Fine structural localization of aldose reductase and ouabain-sensitive $\mathrm{K}(+)$-dependent p-nitro-phenylphosphatase in rat peripheral nerve. Acta Neuropathol (Berl) 81: 529-539

40. Chakrabarti S, Sima AA, Nakajima S et al. (1987) Aldose reductase in the BB-rat. Isolation, immunological identification and localization in the retina and peripheral nerve. Diabetologia 30: 244-251

41. Magnani P, Cherian PV, Gould GW et al. (1996) Glucose transporters in rat peripheral nerve: paranodal expression of GLUT I and GLUT 3. Metabolism 45: 1466-1473

42. Menegoz M, Gaspar P, LeBert M et al. (1997) Paranodin, a glycoprotein of neuronal paranodal membranes. Neuron 19: 319-331

43. Poliak S, Gollan L, Martinez P et al. (1999) Caspr2, a new member of the neurexin superfamily, is localized at the juxtparadnodes of myelinated axons and associates with $\mathrm{K}^{+}$channels. Neuron 24: 1037-1047

44. Davis, JQ, Lambert S, Bernett V (1996) Molecular composition of the node of Ranvier: identification of ankyrinbinding cell adhesion molecules neurofascin (mucin $+/$ third FN III domain-) and NrCAM at nodal axon segments. J Cell Biol 135: 1355-1367

45. Einheber S, Zanazzi G, Ching W et al. (1997) The axonal membrane protein Caspr, a homologue of neurexin IV, is a component of the septate like paranodal junctions that assemble during myelination. J Cell Biol 139: 1495-1506 